感動の瞬間

\title{
合成が苦手な化学者による超単純な 天然物の全合成
}

\author{
Total Synthesis of a Simplest Natural Product by a Clumsy \\ Chemist
}

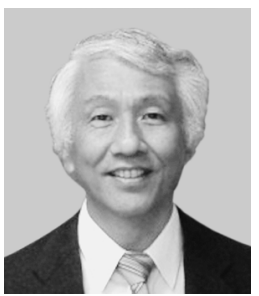

楠見 武德 (東京工業大学理学院特任教授)

Takenori Kusumi

\section{合成実験はとても苦手である。}

東京教育大学の学部 4 年生時代 (故・柿澤 寛教授) から 筑波大学の講師時代初期まで, トリテルペンなどの天然 物全合成を目指して奮闘したが，同僚や後輩達が次々と 良い成果を出すのを横目に, 何をやっても原料回収で, 自嘲的に「立領海舟」と自称していたほどである。

30 代も後半になった 1970 年後半に，合成から海洋天 然物の構造解析に方針転換してから，研究面でようやく 追い風が吹いて来た感がある。最初に手がけた海藻の成 分が幸いなことに未知物であり，60 MHz NMR を用い た初めての「構造決定の論文」が Chemistry Letters ${ }^{1)}$ に 掲載された時の喜びを今でも覚えている。その後, 90 $\mathrm{MHz}$ そして $500 \mathrm{MHz}$ の NMR 装置を操作する機会, さ らに優秀な学生さんたちにめぐまれ，新 Mosher 法を含 むいくつかの満足できる論文に名を連ねることができ た2)

構造決定の研究においては, 機器分析だけではなく, 化学変換などの「ベンチ実験」を導入することにこだわっ たのは，合成で苦しんだ経験のなせる技であり，構造決 定に有機化学的風味を添えることを強く意図したもので ある。

しかし，言うまでもなく，これらの成果は実際に実験 を行った研究室諸氏の努力の賜物であり，彼らと「共に 分かち合った感動の瞬間」は数限りなくある。

\section{コロンビア大学の中西香爾教授研究室で}

では，合成実験の場面で「自分自身の感動の瞬間は？」 と自問してみると, 40 年近く前のコロンビア大学博士

東京工業大学理学院化学系 (152-8551 東京都目黒区大岡山 212-1)

Department of Chemistry, Tokyo Institute of Technology (112-1 Ookayama, Meguro-ku, Tokyo 152-8551, Japan)
研究員時代までさかのぼることになる。ニューヨークの JFK 空港に到着し, わざわざ車で迎えに来てくださった 天然物化学の大御所, 中西香爾(こうじ)教授*から車内 で，「人の大学院生の面倒を見てくれ」と仰せつかった ことから物語が始まる。

到着の翌日, 博士課程大学院生であったBen Liu 君 (現テキサス大学教授) と Conway Chang 君と共に構造 決定の研究を開始した。興味をもったのはConway 君 のテーマである。東アフリカ産植物 Triumfetta rhomboidea から単離されたレタス種子発芽阻害物質(後 に triumferol と命名)が，前任者により純粋な結晶とし て $200 \mathrm{mg}$ ほど得られていた。しかし，長期にわたりそ の構造が決定されておらず，ようやく半年ほど前にそれ らしい構造が推定されたので, その構造を確かめるとい うプロジェクトであった。

Conway 君と実験室で会い, まず ${ }^{1} \mathrm{H}$ NMR スペクト ル $(80 \mathrm{MHz})$ を見せてもらったところ, 三本のシング レット $(\delta 8.33,8.25,8.18)$ があるのみで, それらのうち 8.18 シグナルは $\mathrm{D}_{2} \mathrm{O}$ 添加で消えるため, フェノール性 の $\mathrm{OH}$ であると推定されていた。では, ということで triumferol の溶液を TLC 板にスポットし塩化第二鉄の 水溶液に浸したところ, スポット部が強く青紫に発色 し，フェノール性物質であることが確かになった。こん な簡単な定性試験に彼は素直に驚いてくれたが, この方 法は単純で鋭敏な検出法なので, 以降の実験で triumferol を検出するためのルーチンワークとして使用され た。 ${ }^{13} \mathrm{C} \mathrm{NMR}$ にも三本のシグナル $[\delta 146.1(\mathrm{~d}), 143.4(\mathrm{~d})$, $141.3(\mathrm{~s})$ 】しか現れておらず, きわめて単純な物質であ るように思われた。

なぜこんなに単純そうな物質の構造が長らく決まらな かったのだろう? 問題はマススペクトルにあった。当 時の化学科には EI-MS(電子イオン化法質量スペクトル 装置)がそなわっていたが, 試料を加熱してもスペクト ルには分子イオンピークらしきものが明確には現われ 
ず，結晶である triumferol は「高極性で難揮発性」の物質 であると想定されていた。さらに $\mathrm{m} / \mathrm{z} 300$ 付近にある やや強いピークを，(前任者の誰かが) 分子イオンピーク として推定したため, 単純なへテロ環化合物の対称性を 持つトリマーのような構造が提出されていたのであっ た。その構造を確定すべく, 同じ化学科の合成研究室の 博士研究員が, この「ユニークな天然物」の合成計画を ねっているとのことだった。

念のため実際のマススペクトルを見せてもらったが， 問題とするそのピークはノイズレベルょり少し強いだけ で，とても分子イオンピークには思えない。ところが， $m / z 149$ にチャートから振り切れた強いピークが現れて いた。自分の経験から，これはフタル酸ジオクチル $\left[\mathrm{C}_{6} \mathrm{H}_{4}\left(\mathrm{CO}_{2} \mathrm{C}_{8} \mathrm{H}_{17}\right)_{2}\right]$, すなわち真空ポンプのオイルに特 有のフラグメントピーク(1)であることがすぐにわかっ た。要するに天然物ではなく, 真空ポンプオイルのマス スペクトルを解析していたのであった。フタル酸ジオク チルはプラスチックの可塑剤としても使われ, 試薬ビン のキャップやビニールチューブから簡単に溶媒に混入す るため, 合成実験でもしばしばコンタミとして悩まされ ていた経験が役に立ったのである。

EI-MS を測定するためには，まず試料を小さな石英 セルに入れ，それを常圧にしたチャンバーのセルホル ダーにセットする。チャンバーを脱気したのち, 高真空 下で石英セルを加熱し, 生じた蒸気に電子ビームを当て て分子をイオン化する仕組みである。

ある夜, ブロードウェイ 125 丁目にあるアパートに帰 宅後，ビールを飲みながらふと考えた。“ひょっとする と, EI-MS 測定に扔いて, 試料が不揮発性であるため に分子イオンピークが出なかったのではなく, 加熱し電 子ビームを当てる以前に真空中で試料が蒸発して無く なってしまったのではないか？すなわち, NMRスぺ クトルが示すように, triumferol は実は単純な物質で, 結晶であるにもかかわらず揮発性物質なのではないのた ろうか?”

さっそく翌日, 試料を入れた石英セルを液体窒素で泠 却し, チャンバーに入れて減圧し, 加熱することなくた だちに電子ビームを当てたところ， $\mathrm{m} / z 85$ に非常に強 い分子イオンピークを観測することができた。これがコ ロンビア大学に扔ける「最初の感動の瞬間」であった。

この分子量と元素分析值から分子式 $\mathrm{C}_{3} \mathrm{H}_{3} \mathrm{NO}_{2}$ がただ ちに決定でき，NMR, IR, UV スペクトルからその構造 として 3 個のヒドロキシイソオキサゾール (2-4)にしほ ることができた(図 1)。

こんな単純な化合物が未知物であるはずがなく，念の ため図書館で分厚い Chemical Abstract の冊子(紙媒体) を，指をなめなめ(昔の慣用語であり実際になめたわけ
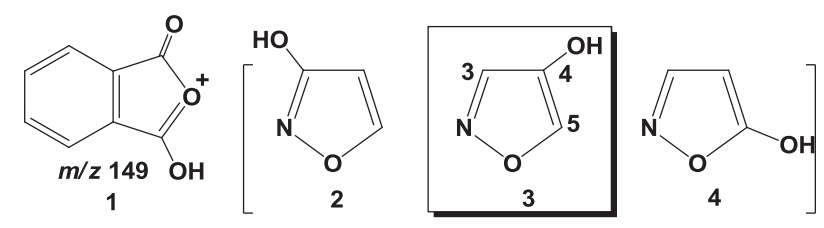

Fig. $1 \mathrm{~m} / z 149$ fragment (1) in the MS of dioctyl phthalate. Three possible structures 2-4 assumed for the natural product, 3 being the genuine one named triumferol.

ではない)ページをめくり検索したところ，2 と４はケ 卜またはエノール型として既知物であることがすぐわ かった。しかし，3すなわち4-ヒドロキシイソオキサ ゾールは丸 2 日かけた検索 (現在ではネットで数分で終 わるであろう)の結果, 信じられないことに「未知化合 物」であることが判明した。

\section{苦手な合成をやる羽目に一一雷酸水銀こわい!}

さて，かつては「玄領海舟」として名を馳せ・・なかっ た 10 数年のあいだ合成に携わった者が, たかだか炭素 3 個の化合物を目の前にして身を引くことはできない。 全合成して構造を確認することとなったのは当然の流れ である。「こんなものすぐに合成できる」と啖呵を切った ものの，よく考えてみればこれほど単純な化合物がそれ まで未知物であったのには, 何かふかーい訳があったは ずである。合成実験を始めてその理由を痛いほど思い知 らされることになった。

4-ヒドロキシイソオキサゾールの 3 位や 5 位に置換 基を持つ誘導体は知られているので, それらの合成法を 参考にして2-ヒドロキシマロンジアルデヒドおよびそ の誘導体 (5: $\left.\mathrm{R}=\mathrm{H}, \mathrm{Ac}, \mathrm{Me}, \mathrm{PhCH}_{2}\right)$ (図 2) さらにはそれ らのビス(ジエトキシアセタール)体にヒドロキシルアミ ンを作用させたが, 複雑な混合物が生成するのみで, イ ソオキサゾール骨格を持つものを痕跡すら得ることがで きなかった。

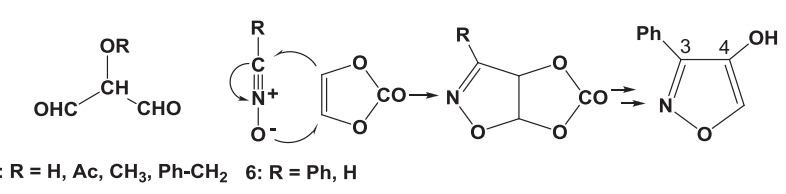

Fig. 2 2-Oxygenated malondialdehyde derivatives (5). Synthesis of 3-phenyl-4-hydroxyisoxazole via 1,3-dipolar addition of nitrile oxide $6(\mathrm{R}=\mathrm{Ph})$ to vinylene carbonate.

留学前の筑波大学の研究室では, ニトロンやニトリル オキシドのオレフィンに対する 1,3-双極子付加反応によ りイソオキサゾリジンやイソオキサゾリンをつくり，そ こからアルカロイドやテルペンの全合成を行う研究を経 験してきた。そこで，3-フェニル-4-ヒドロキシイソオ キサゾールを, ベンゾニトリルオキシド $(6: \mathrm{R}=\mathrm{Ph})$ と炭 
酸ビニレンとの 1,3-双極子付加反応を経て得る(図 2) と いう論文 ${ }^{3)}$ に注目した。そのためには 6 の R が H であ る必要がある。

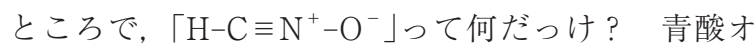
キシド? いやいや, これってフルミン酸, すなわち爆 発性で有名な雷酸ではないか!・・・しかし恐れていて は実験ができない。同じ爆発性のジアゾメタンを蒸留し た経験を何回も持つ自分ではないか。ということで，と にもかくにも雷酸を作ることにした。雷酸は起懪剤とし て有名な雷酸水銀 $(\mathrm{HgCNO})$ を酸分解して得られる。文 献によれば雷酸水銀は驚くほど簡単な方法で得られるよ うだ。

ドラフト内で 1 グラムの水銀を蒸発皿にとり，濃硝酸 を注ぐ。発熱反応が起こり水銀は硝酸水銀となり溶解す る。この溶液にエチルアルコールを注ぐ。しばらくする と, これまで見たことも経験したこともないような濃厚 で不吉な灰色の煙がもくもくと立ち上がり，その中から 「アラジンの魔人でも現れるのでは? 」と逃げることも忘 れ，ドラフトの前で茫然と立ちすくんでしまった。これ が「第二の感動の瞬間」である。

反応がおさまり，ドラフトを満たしていた灰色の煙も なくなって，恐れをなして退避していた同室のJohn Snyder 博士 (現ボストン大学教授)が戻ったのち, 沈殿 した雷酸水銀をろ過により取り出し, 酸処理して雷酸を 遊離させた。これに炭酸ビニレンを作用させたが，びく びくしながらやった実験でもあり，まともな生成物を得 ることはできなかった。当然のことながら，この恐ろし い実験を繰り返す勇気もなかった。

その後, 試みた反応も良い結果をもたらさなかった。 例えば，4-ブロモイソオキサゾール (7: X=Br)（図 3)に n-ブチルリチウムを作用させ生じるアニオンに $\mathrm{B}\left(\mathrm{OCH}_{3}\right)_{3}$ を反応させ，さらに過酸化水素による酸化で 3 を得る試みを行った。しかし，n-ブチルリチウムを加 えた瞬間にイソオキサゾール環の 3 位のプロトンが引き 抜かれて，環開裂反応が起こり複雑な混合物を与えてし まった。また，イソオキサゾールと $\mathrm{NO}_{2}{ }^{+} \mathrm{BF}_{4}{ }^{-}$から高収 率で得られる 4-ニトロイソオキサゾール $\left(7: \mathrm{X}=\mathrm{NO}_{2}\right)$ を
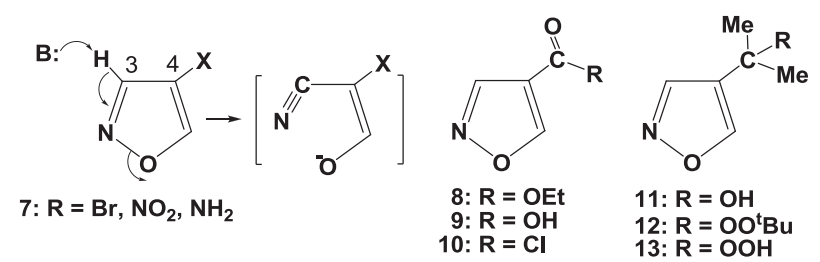

Fig. 3 Destruction of 4 -bromoisoxazole $(7: \mathrm{X}=\mathrm{Br})$ by abstraction of 3-proton by a strong base. Isoxazole-4-carboxylic acid (9), and its ester (8) and chloride (10). The key materials (11-13) which led to synthesis of triumferol (3).
$\mathrm{Al}-\mathrm{Hg}$ で還元して得られるアミン $7\left(\mathrm{X}=\mathrm{NH}_{2}\right)$ に Sandmeyer 反応を試みたが, 水酸基への変換は起こら ず分解反応が起こるのみ。

さすがに落ち込んでしまったが，よく考えてみると， きわめて単純なこの 4-hydroxyisoxazole(3)がこれまで 未知物であったのは, 先人たちもいろいろな方法で合成 を試していたが，ことごとく失敗で「この化合物は不安 定で取り出すことはできない, 存在すら疑わしい」とい うような推定をしていたのではないだろうか？しか し，われわれは現実に3を安定な結晶として所有してお り, 先人たちよりは圧倒的に有利な立場にあるはずであ る。ネガティブな状況に自分を追い达んではならない。

\section{同僚から助け舟が}

さいわいなことに，この時点で同じ中西研の博士研究 員であった秋田弘幸博士 (現東邦大学名誉教授) から, 塩 基性ではなく酸性条件下でフェノールを合成するルート を教えていただいた。誌面節約のため文中に書くと $\left\lceil\mathrm{Ar}-\mathrm{CMe}_{2}-\mathrm{OH}+{ }^{\mathrm{t}} \mathrm{BuOOH}+\mathrm{H}^{+} \rightarrow\left(\mathrm{Ar}-\mathrm{CMe}_{2}-\mathrm{OO}^{t} \mathrm{Bu}\right) \mathrm{H}^{+}\right.$ $\rightarrow$ (転位反応/加水分解 $) \rightarrow \mathrm{Ar}-\mathrm{OH}$ 〕すなわちフェノール 製造のためのクメン法の類似法 ${ }^{4}$ である。

さっそくイソオキサゾールカルボン酸エステル (8)を 調製し MeMgI と反応させたところ，やはり 3 位のプロ トン引き抜きが起こり複雑な生成物を与えてしまった。 しかし，その中からほんのわずかな量 $(<1 \mathrm{mg})$ のジメ チルアルコール体11を単離することができた。なけな しの 11 に ${ }^{\mathrm{t}} \mathrm{BuOOH}$ を加え酢酸-硫酸で処理し，TLCを 展開したところ，目的物 3 と同じ位置にかすかなスポッ トが認められ(UV), しかもそのスポットが塩化鉄呈色 反応で弱いながら陽性を示したので, 恐らく合成に成功 したのだろうと考えた。しかし，あまりにも少量の実験 であったので再現性を見なくては確信が持てない。

\section{ロを滑らし苦境に・・・・}

しかしその直後, 中西先生とたまたまエレベーターで 一緒になり，「どうもできたらしいですよ」と口をすべら せてしまった。中西先生も半分あきらめていたところの 成功の知らせに大喜びで, 化学科の先生方に「ようやく 合成できた」とふれまわってしまったらしい。何しろ単 純な化合物の合成なので，それまでにもGilbert Stork 研やClark Still 研の院生や博士研究員が興味を持ち, 「これでやれば絶対にできる」と様々な合成ルートを提案 しにやってきていたので，うわさはたちまち広がり，そ の後, エレベーターで出会った Stork 先生に「おめでと う」とまで言われてしまった。

舞い上がってはいられないので, すぐに11を数十 $\mathrm{mg}$ 作り, 数 $\mathrm{mg}$ スケールで実験を繰り返してみたとこ 
ろ全く3が生成しない!! ひたすらうろたえて，その 後, 数日間はできるだけ人と顔を合わせないようにし て，ひそかに実験を繰り返したが，結果は再現性良くネ ガティブ。いまさら「あれ，間違いでした」とは言えな い。「そっと日本に帰ろうか」とまで考えたが, 少し冷静 になって生成物の TLCを再検討してみた。それまでは 3 を検出することばかり考え，反応生成物を TLCで展 開後, UVランプと塩化鉄反応のみを使用していたのた が, 念のため常法にもどり, アニスアルデヒド・硫酸で 発色させたところ, TLCの上端に，加熱すると鮮やか な空色に発色し, その後, すぐに茶色に変色する濃い久 ポットがあるのに気がついた。溶媒の極性を下げ，その 独特な発色を示す物質をかき取ったところ，なんと転位 反応前の過酸化エーテル 12 であることがわかった。こ れを再度, 酢酸・硫酸で処理したところ, 低収率ではあ るが 3 が生成し， triumferol と同定することができた。 結局, 最初の TLC スケール実験では, 11 に対して酸が 大過剩であったため 12 が 3 へ変換したが，その後の 11 の量を多く使用した実験では，酸の量を慎重に制御し過 ぎたため反応が 12 で止まってしまったものと思われる。

\section{全合成の体裁を整える}

こうして3が得られ，なんとか恥もかかずに済んだの であるが，「全合成」としては収率的にも段数的にも不満 足な工程である。まずはエステル 8 に対する Grignard 反応で 3-プロトンの引き抜きを制御できないものだろ うか? そこで, カルボン酸 9 を五塩化リンで酸塩化物 10 として活性化し, MeMgI を2 当量反応させたところ $75 \%$ の収率で 11 を得ることができた。次の「クメン類 似反応」の改良であるが，酸性条件下で過酸化物 13 がで きれば，酸処理により転位反応が起こるはずだと考え た。そこで氷冷した濃硫酸と $30 \%$ 過酸化水素の混合物 を, アルコール体 $11(2.8 \mathrm{~g})$ のジクロロメタン溶液に, ジクロロメタンがおだやかに還流する速度で滴下した。 反応混合物に対し抽出操作を行った後，溶媒を除去した
ところ $1.7 \mathrm{~g}(91 \%)$ の純粋な 3 をきれいな結晶として得る ことができた ${ }^{5)}$ 。れが「三番目の感動の瞬間」である。

きわめて単純な物質ではあるが，発芽抑制作用という 生理活性を有する新化合物であるため, 帰国後「第 24 回 天然有機化合物討論会 (1981 年)」で口頭発表させていた だいた。格調高いこの討論会で行われた口頭発表で，炭 素 3 個で分子量 85 の天然物合成は, 現在でも「最小記録 かな？」と密かに自負しているのだが・・。

\section{文 献}

* 本年 3 月 28 日に逝去。ご冥福を祈ります。

1) T. Kusumi, Y. Shibata, M. Ishitsuka, T. Kinoshita, H. Kakisawa, Chem. Lett., 8, 277 (1979)

2) 抜粋: (a)I. Ohtani, T. Kusumi, Y. Kashman, H. Kakisawa, J. Am. Chem. Soc., 113, 4092 (1991); (b) M. O. Ishitsuka, T. Kusumi, H. Kakisawa, J. Am. Chem. Soc., 112, 8180 (1990); (c) T. Kusumi, H. Tokahashi, P. Xu, T. Fukushima, Y. Asakawa, T. Hashimoto, Y. Kan, Y. Inouye, Tetrahedron Lett., 35, 4397 (1994); (d) T. Yabuuchi, T. Kusumi, J. Am. Chem. Soc., 121, 10646 (1999); (e) K. Nii, K. Tagami, K. Matsuoka, T. Munakata, T. Ooi, T. Kusumi, Org. Lett., 8, 2957 (2006); (f) R. Ohkura, K. Kito, M. Namikoshi, T. Kusumi, J. Org. Chem., 73, 4245(2008); (g) M. Iida, T. Ooi, K. Kito, S. Yoshida, K. Kanoh, Y. Shizuri, T. Kusumi, Org. Lett., 10, 845 (2008)

3) G. Desimoni, P. Gruenanger, S. Serve, Ann. Chim. Rome., 58, 1363(1968)

4) A. W. Burgstahler, L. R. Worden, J. Am. Chem. Soc., 86, 96 (1964)

5) T. Kusumi, C. C. Chang, M. Wheeler, I. Kubo, K. Nakanishi, H. Naoki, Tetrahedron Lett., 22, 3451 (1981)

(2019 年 2 月 18 日受理)

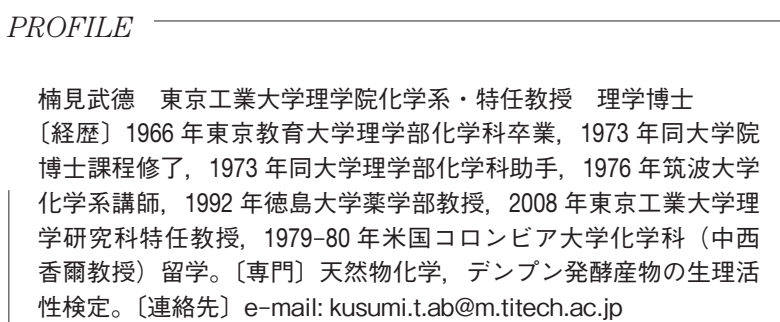

性検定。〔連絡先〕e-mail: kusumi.t.ab@m.titech.ac.jp 